\title{
Internal Control, External Audit and Corporate Cash Flow Risk
}

\author{
Wanting Liu ${ }^{1}$, Qianyu Zhao ${ }^{1}$, Gang Fu, ${ }^{2, *}$ \\ ${ }^{1}$ College of management, Sichuan Agricultural University, Chengdu, China \\ ${ }^{2}$ Sichuan Vocational College of Finance and Economics, Chengdu, China
}

\begin{abstract}
Based on the sample of A-share listed companies in Shanghai and Shenzhen from 2014 to 2019, this paper empirically tests the impact of internal control and external audit on corporate cash flow risk and the interaction between the two in affecting cash flow risk. The results show that high-quality internal control and external auditing can independently reduce corporate cash flow risks, and the two play a substitute effect in this process. The research conclusions expand the impact of the company's internal and external governance mechanisms on cash flow risks, and are of great significance for companies to effectively use internal and external resources to prevent and manage cash flow risks.
\end{abstract}

\section{INTRODUCITIN}

Cash flow is the flow of life for an enterprise, and its sufficient stability is a necessary condition for the survival and sustainable development of an enterprise. However, due to the uncertainty of the internal and external environment, it may cause abnormal fluctuations in cash flow during the production and operation of the enterprise, that is, cash flow risk. Cash flow risk, as an important indicator reflecting the financial operation of a company, not only reveals the safety and stability of the company's capital operations, but also serves as a leading signal for corporate risk management [1] and a warning device for financial crises [2]. In recent years, under the multiple impacts of global trade protectionism and the new crown epidemic, economic uncertainty has continued to rise, and cash flow risks have become the key to the survival of enterprises. Especially after the subprime financial crisis, the sudden outbreak of the new crown pneumonia in early 2020 has once again caused countless companies to suffer unprecedented cash flow shocks. According to a survey conducted by Zhu Wuxiang and others on the impact of the epidemic on 995 small and medium-sized enterprises in China at the beginning of the epidemic, $85 \%$ of the enterprises said that the funds could be maintained for up to 3 months, while less than $10 \%$ said that the funds could be maintained for more than 6 months [3]. Many large companies have drastically laid off their employees and reduced their business scale due to poor cash flow. Small and medium-sized enterprises are struggling and are in bankruptcy due to shortage of cash flow or even cut off. It can be seen that in the current complex background of the external development environment, exploring how to effectively prevent and manage cash flow risks is of great significance for improving the overall risk management capabilities of enterprises and promoting the overall economic development of our society.
The risk of cash flow stems from the uncertainty of the internal and external environment in which the company is located. The uncertainty of the external environment is objectively present and cannot be avoided by any company. In the case of the same external environmental factors, the cash flow risk status of different companies is not the same, or even very different. The fundamental reason lies in the uncertainty of the company's internal environment. This type of uncertainty is determined by the company's own operating and management conditions. It will not only directly increase the uncertainty of future cash flow [4], but may also strengthen the impact of fluctuations in external environmental factors on cash flow. Therefore, effective prevention and control of that is the key to modern enterprise cash flow risk management. The essence of this uncertainty lies in the problems of "adverse selection" and "moral hazard" inherent in the agency relationship at all levels within the enterprise. Due to the separation of the two powers of modern enterprises, information asymmetry and agency conflicts are widespread. When an enterprise maintains high liquidity in order to guarantee its own normal operation and development, cash flow, the most liquid asset, is often very easy to become a low-cost resource for abuse or low consumption by insiders. The specific manifestation is: Managers' inefficient investment, corrupt consumption, and malicious embezzlement, embezzlement, and "empty" behaviors by major shareholders, which will not only directly increase the pressure on the company's capital chain and greatly affect the normal turnover of funds, but also further cause the ineffective or inefficient allocation of resources by affecting the effectiveness of the company's operating efficiency, thereby triggering cash flow risk.

In short, information asymmetry and agency problems are the fundamental causes of cash flow risk. This means that to reduce cash flow risk from the source, a series of supervisory, restrictive, and incentive compatible

*fugang96@sicau.edu.cn 
institutional arrangements must be established to alleviate information asymmetry and Agency problem. For this reason, good corporate governance mechanisms are placed high hopes. Internal control is an important internal measure in the current corporate governance structure, as well as a safety net and firewall for the company's comprehensive risk management. Its most important and fundamental purpose is to control risks [5]. The internal control system affects the inflow, outflow, occupancy and reserve of the company's cash flow by acting on all levels and all activities within the enterprise, and plays an important role in cash flow management. Existing documents have proved that high-quality internal control can significantly reduce the company's cash flow risk [6]. In addition, external independent audit, as an important external governance arrangement, plays the role of information intermediary and external regulator in the market [7], which is reducing agency costs [8], improving investment efficiency [9], and restraining the risk of stock price collapse [10] and other aspects play an important role. However, can external audit effectively reduce the company's cash flow risk? Furthermore, as internal and external governance mechanisms of the enterprise, what kind of interaction does internal control and external audit have in terms of the governance effect on cash flow risk? Is there a substitution effect or a complementary effect? So far, there is no relevant literature on these issues at home and abroad. Based on this, this article uses the 2014-2019 Shanghai and Shenzhen A-share listed companies as the research object to empirically analyze the impact of internal control and external audit on cash flow risk, and the two governance mechanisms of internal control and external audit in the process of affecting cash flow risk The coupling interaction relationship.

The marginal contribution of this article lies in: innovatively researching the governance effects of external audit supervision based on cash flow risk, which not only enriches the research content of cash flow risk influencing factors, but also expands the study of the economic consequences of external audits; at the same time, there is no consensus on the interaction between internal control and external auditing in terms of corporate governance effects at present. This article examines the alternative relationship between the two from the perspective of cash flow risk for the first time, enriching the research in this area. The purpose of this article is to provide empirical evidence and guidance for the prevention and governance of corporate cash flow risks from the internal and external governance of the company.

\section{Theoretical analysis and hypothesis}

\subsection{Internal control and cash flow risk}

This article believes that internal control can effectively reduce cash flow risks from the following three aspects.

First, internal control can reduce cash flow risk by alleviating agency problems. As a supervision and restriction mechanism, internal control uses contracts to ensure the reasonable distribution of rights, responsibilities and interests of various stakeholders within the enterprise, effective checks and balances of power, and optimal arrangements for processes, and the effective implementation of various internal contracts [11], thereby alleviating The principal-agent problem reduces agency costs. In this process, high-quality internal control can better coordinate and balance the different interest demands between the principal and the agent, curb the self-interested motivation of the management or major shareholders, and avoid and promptly suppress the occurrence of the above-mentioned opportunistic behavior. And its adverse effects, thereby providing effective protection for the cash flow from misuse, abuse or inefficient consumption from the insiders of the enterprise, improving the efficiency of capital allocation, and reducing the possibility of cash flow damage.

Second, internal control can reduce cash flow risks by improving the quality of accounting information. Providing reasonable assurance for the reliability of financial reports is an important goal of internal control. Under the condition that the internal control system of the enterprise is perfect and efficient, management's opportunistic accounting policy selection behavior can be effectively suppressed, and the possibility of misstatement, understatement, understatement and false statement in the disclosure of financial report information is greatly reduced, thereby improving accounting information Quality [12], reduce the risk of information asymmetry. On the one hand, this helps investors to clarify the real situation of business operations, identify the opportunistic motives of management authorities, realize effective external supervision of cash flow, and ensure the efficiency of cash flow use and value appreciation; it also helps to enhance the relationship with creditors The trust relationship between them enhances financing capabilities, reduces financing costs, and avoids cash flow risks caused by insufficient cash payment capabilities.

In addition, internal control can also reduce cash flow risks by improving the efficiency of business operations. As a guarantee system for enterprise management, internal control can encourage management to work hard through its incentive and supervisory functions to improve the ability and efficiency of enterprise group decision-making [13], and check and balance the daily behavior of employees in various departments to ensure effective implementation of decisions. Ensure the stable operation of the enterprise, improve the overall operating efficiency and effectiveness of the enterprise, and promote the operation and turnover of the enterprise's cash flow to be carried out in accordance with the established goals and tracks under more scientific and strict regulations, supervision and control. On the one hand, this means the acceleration of cash turnover rate and the improvement of working capital efficiency. On the other hand, it will also promote the increase of cash flow from operating activities as a company's "hematopoietic" machine, and enhance the company's operating capacity, cash-capability and profitability. Ability to improve the company's cash flow management and risk response level to a certain extent.

Based on the above analysis, this article proposes the following hypotheses: 
H1: When other conditions are established, highquality internal control can help reduce corporate cash flow risks.

\subsection{External audit and cash flow risk}

External audit is a third-party supervision and guarantee mechanism in the corporate governance system that is independent of the principal and the agent. It relies on the independence and professional ability of the auditor to provide external information users with a third-party on the reliability of corporate financial report disclosure It is confirmed that it plays an important role in alleviating information asymmetry and reducing agency costs [14]. Similar to internal control, the improvement of external audit quality can also reduce cash flow risk to a certain extent. On the one hand, companies choosing high-quality audits can ensure the fairness, authenticity and reliability of financial report information disclosure, and send corresponding positive signals to the outside world, which can enhance the symmetry of information among parties to the contract to a greater extent, and curb adverse selection and moral hazard. , And ease financing constraints, reduce cash flow risks. On the other hand, the higher the audit quality, the more vigilant and effective supervision and restriction on the infringement of insider interests and other phenomena can be maintained. As far as cash flow is an important part of financial statements, due to its inherent risks and closely related to operation, investment, and financing activities, high-quality auditors will formulate more effective and targeted The audit procedures are audited, and the economic activities closely related to cash flow are inspected, tracked and disclosed with more cautious professional suspicion and prudent accounting policies, thereby increasing the cost and risk of management and major shareholders seeking private benefits through cash assets. In other words, strict external audit supervision and prestigious auditor review means strong pre-deterrence and post-mortem supervision, which can more effectively restrain the opportunistic behavior of management and major shareholders, ensure the rational allocation and effective use of funds, and restrain cash flow The occurrence and evolution of risks. On the contrary, when the external audit supervision is inefficient or invalid, corporate information asymmetry and agency problems are prominent, which will undoubtedly increase the probability of cash flow risks. Based on this, the following assumptions are made:

$\mathrm{H} 2$ : When other conditions are established, highquality external audits can help reduce corporate cash flow risks.

\subsection{The impact of internal control and external audit on corporate cash flow risk}

From the previous analysis, we can see that both internal control and external audit can independently manage cash flow risks. According to the principles of microeconomics, if enterprises are regarded as consumers, and "internal control" and "external audit" are regarded as two commodities, they both have the same cash flow risk management utility and can function independently, then this There must be an alternative relationship between the two. Or it can be explained in this way: high-quality internal control means that the company's operation and management process can be fully and effectively supervised, which can better restrain the opportunistic behavior of management and major shareholders, limit malicious manipulation of accounting information, and reduce financial The possibility of material misstatement in the statement. The risk of major misstatement is the core of audit risk. The probability of an auditor discovering and reporting a major misstatement determines the quality of external audits. Therefore, effective internal control can "squeeze out" the governance effect of external audit on cash flow risk from the level of "process supervision". Conversely, when the company's own internal control construction is not perfect or the implementation is inefficient, hiring highquality external audits can also make up for the former's "process supervision" deficiencies from the "result supervision" level, thereby reducing the existing or future May further expand the cash flow loss. Based on this, the following assumptions are made:

H3: When other conditions are established, internal control and external audit have a substitution effect in the process of managing cash flow risks.

\section{Research design}

\subsection{Data sources}

This paper selects A-share listed companies on the Shenzhen and Shanghai stock exchanges from 2014 to 2019 as the initial research sample, and screens them according to the following procedures: exclude companies in the financial and general industries; exclude companies that simultaneously issue $\mathrm{H}$ shares, $\mathrm{B}$ shares or other foreign shares; eliminate ST and *ST company samples; eliminate audited companies with different domestic and overseas firms; eliminate missing value samples. After screening, 13691 valid samples were finally obtained. In addition, this paper performs a winsorize up and down $1 \%$ on the main continuous variables to eliminate the influence of extreme values. The data in this article mainly come from CSMAR and DIB, and finally used for data analysis by STATA16.0.

\subsection{Definition of variables}

\subsubsection{Cash flow risk}

According to the previous definition of cash flow risk, this article mainly focuses on the operational fluctuations of corporate cash flow. Therefore, referring to the practice of Gu Naikang et al. [15] and Chen Zhibin et al. [1], this article uses the standard deviation of the company's "net operating cash flow/total assets" for three consecutive years as a proxy for cash flow risk. 


\subsubsection{Internal control quality}

This article selects the DIB internal control index to measure the quality of enterprise internal control. The index comprehensively reflects the efficiency and effect of the implementation of internal control of listed companies from the five dimensions of internal control compliance, reporting, asset safety, operation and strategic goal realization. It is objective and scientific and has been widely used in academia and practice. And recognition. In order to ensure the same comparison of the data, the natural logarithm of the index plus one is used. The larger the value obtained, the higher the quality of the internal control of the enterprise.

\subsubsection{External audit quality}

A large number of studies have shown that under the same conditions, as the size of the firm increases, the more it can provide higher-quality audits. Therefore, this article draws on the practice of scholars such as Cao Guohua [7], and refers to the Information on the Top 100 Accounting Firms in Comprehensive Evaluation issued by the AICPA during the sample period. If the accounting firm that company hires is the international "Big 4" or domestic top 10 that year, the value is 1 , otherwise it is 0

\subsubsection{Control variables}

This article selects the following variables that may have a greater impact on cash flow risks: enterprise size, assetliability ratio, cash flow, cash holding level, net working capital, growth GRWOTH, investment expenditure, return on assets, dividend payment, market competition, and set up industry and year dummy variables to control the industry and year impact. The specific variable definitions are shown in Table 1.

\begin{tabular}{|c|c|l|}
\multicolumn{1}{c|}{ Table1. } & \multicolumn{1}{c|}{ Variable definitions } \\
\hline $\begin{array}{c}\text { Variable } \\
\text { type }\end{array}$ & Variable & \multicolumn{1}{c|}{ Indicator description } \\
\hline Explained & CVAR & $\begin{array}{l}\text { Standard deviation from t-2 to } \\
\text { t (net operating cash flow /total } \\
\text { assets) }\end{array}$ \\
\hline \multirow{5}{*}{ Explanatory } & IC & $\begin{array}{l}\text { DIB internal control index }+1 \\
\text { and then take the natural } \\
\text { logarithm }\end{array}$ \\
\cline { 2 - 3 } & AUDIT & $\begin{array}{l}\text { If the auditing unit is the } \\
\text { international "Big 4" or } \\
\text { domestic top 10 accounting } \\
\text { firm, the value is 1, otherwise } \\
\text { it is 0 }\end{array}$ \\
\hline \multirow{5}{*}{ Controls } & SIZA & $\begin{array}{l}\text { Enterprise size, the natural log } \\
\text { of a company's total assets }\end{array}$ \\
\cline { 2 - 4 } & LEV & $\begin{array}{l}\text { Asset-liability ratio, total } \\
\text { liabilities/total assets }\end{array}$ \\
\cline { 2 - 4 } & NCF & $\begin{array}{l}\text { Cash flow, net cash flow from } \\
\text { operating activities/total assets }\end{array}$ \\
\cline { 2 - 4 } & CASH & $\begin{array}{l}\text { Cash holding level, cash and } \\
\text { cash equivalents /total assets }\end{array}$ \\
\cline { 2 - 3 } & NWC & $\begin{array}{l}\text { Net working capital, (current } \\
\text { assets-current liabilities-cash } \\
\text { and cash equivalents at the end } \\
\text { of the period)/total assets }\end{array}$ \\
\hline
\end{tabular}

\begin{tabular}{|c|c|l|}
\hline GRWOTH & $\begin{array}{l}\text { Growth rate of company } \\
\text { operating income, operating } \\
\text { income of this year/operating } \\
\text { income of last year-1 }\end{array}$ \\
\cline { 2 - 3 } INVET & $\begin{array}{l}\text { Investment expenditure, (cash } \\
\text { paid for the purchase and } \\
\text { construction of fixed assets, } \\
\text { intangible assets and other } \\
\text { long-term assets-cash received } \\
\text { from the disposal of fixed } \\
\text { assets, intangible assets and } \\
\text { other long-term assets)/total } \\
\text { assets }\end{array}$ \\
\cline { 2 - 3 } & ROA & $\begin{array}{l}\text { Return on assets, net profit/the } \\
\text { average total capital }\end{array}$ \\
\cline { 2 - 4 } & $\begin{array}{l}\text { Dividend payment, If the cash } \\
\text { dividend is paid in the current } \\
\text { period, the value is 1, } \\
\text { otherwise it is 0 }\end{array}$ \\
\hline DIV & $\begin{array}{l}\text { Market competition, the } \\
\text { natural logarithm of the } \\
\text { number of listed companies in } \\
\text { the industry }\end{array}$ \\
\hline COMP & Industry virtual variabl \\
\hline YEAR & Annual dummy variable \\
\hline &
\end{tabular}

\subsection{Model construction}

For H1, the paper constructs the model (1) [1]:

$$
\text { CVAR }=\alpha_{0}+\alpha_{1} I C+\alpha_{2} \text { Controls }+\sum I N D+\sum Y E A R+\varepsilon
$$

For H2, the paper constructs the model (2) [1]:

$C V A R=\beta 0+\beta 1 A U D I T+\beta 2$ Controls $+\sum I N D+\sum Y E A R+\varepsilon$

For H3, the paper constructs the model (3) [16]:

$$
\begin{gathered}
\text { CVAR }=\delta_{0}+\delta_{1} I C+\delta_{2} A U D I T+\delta_{3} I C * A U D I T+ \\
\delta_{4} \text { Controls }+\sum I N D+\sum Y E A R+\varepsilon
\end{gathered}
$$

\section{Empirical results and analysis}

\subsection{Descriptive statistics}

It can be seen from the table 2 that the average value of the cash flow risk (CVAR) of the selected sample is 0.0421 , the median is 0.0322 , the standard deviation is 0.0348 , and the minimum and maximum values are 0.0026 and 0.1936 , respectively, indicating that the overall cash flow risk of the sample companies is not The internal control quality (IC) average value is 6.2883 , and the standard deviation is 1.0731 , indicating that the overall internal control quality of the sample companies is relatively high. In recent years, China's internal control construction has been effective, but there are still some companies There is a big gap. On average, $59.62 \%$ of the sample enterprises hired the top 14 to conduct audits, indicating that domestic accounting firms have gradually become bigger and stronger under the impetus of the government. 
Table2. Descriptive statistics

\begin{tabular}{|c|c|c|c|c|c|c|}
\hline VARIABLE & N & mean & Sd & min & P50 & max \\
\hline CVAR & 13691 & 0.0421 & 0.0348 & 0.0026 & 0.0322 & 0.1936 \\
\hline IC & 13691 & 6.2883 & 1.0731 & 0.0000 & 6.4913 & 6.6806 \\
\hline AUDIT & 13691 & 0.5962 & 0.4907 & 0.0000 & 1.0000 & 1.0000 \\
\hline SIZE & 13691 & 22.2876 & 1.1769 & 20.0320 & 22.1502 & 25.8440 \\
\hline LEV & 13691 & 0.4267 & 0.1997 & 0.0612 & 0.4168 & 0.8838 \\
\hline NCF & 13691 & 0.0459 & 0.0671 & -0.1554 & 0.0448 & 0.2392 \\
\hline CASH & 13691 & 0.1442 & 0.1080 & 0.0105 & 0.1146 & 0.5413 \\
\hline NWC & 13691 & 0.0718 & 0.1965 & -0.4211 & 0.0723 & 0.5672 \\
\hline GROWTH & 13691 & 0.1809 & 0.4471 & -0.5576 & 0.1027 & 2.9100 \\
\hline INVEST & 13691 & 0.0409 & 0.0418 & -0.0252 & 0.0289 & 0.1996 \\
\hline ROA & 13691 & 0.0360 & 0.0652 & -0.2686 & 0.0356 & 0.2087 \\
\hline DIV & 13691 & 0.7368 & 0.4404 & 0.0000 & 1.0000 & 1.0000 \\
\hline COMP & 13691 & 5.3420 & 0.9018 & 2.8332 & 5.4072 & 6.7190 \\
\hline
\end{tabular}

\subsection{Regression analysis}

Table3. Regression results

\begin{tabular}{|c|c|c|c|}
\hline & $\begin{array}{c}(1) \\
\text { CVAR }\end{array}$ & $\begin{array}{c}(2) \\
\text { CVAR }\end{array}$ & $\begin{array}{c}(3) \\
\text { CVAR }\end{array}$ \\
\hline IC & $\begin{array}{c}-0.0018^{* * *} \\
(-4.4318)\end{array}$ & & $\begin{array}{c}-0.0017^{* * *} \\
(-4.4250)\end{array}$ \\
\hline AUDIT & & $\begin{array}{l}-0.0020^{* *} \\
(-2.2137)\end{array}$ & $\begin{array}{l}-0.0019^{* *} \\
(-2.1645)\end{array}$ \\
\hline IC*AUDIT & & & $\begin{array}{l}0.0018^{* *} \\
(2.3409)\end{array}$ \\
\hline SIZE & $\begin{array}{l}-0.0057^{* * *} \\
(-11.0715)\end{array}$ & $\begin{array}{l}-0.0056^{* * *} \\
(-10.9588)\end{array}$ & $\begin{array}{l}-0.0056^{* * *} \\
(-10.9067)\end{array}$ \\
\hline LEV & $\begin{array}{l}0.0459^{* * *} \\
(11.6592)\end{array}$ & $\begin{array}{l}0.0464^{* * *} \\
(11.8208)\end{array}$ & $\begin{array}{l}0.0460^{* * *} \\
(11.7193)\end{array}$ \\
\hline $\mathrm{NCF}$ & $\begin{array}{c}0.0071 \\
(0.8202) \\
\end{array}$ & $\begin{array}{c}0.0078 \\
(0.9095) \\
\end{array}$ & $\begin{array}{c}0.0073 \\
(0.8531) \\
\end{array}$ \\
\hline CASH & $\begin{array}{c}0.0239^{* * *} \\
(5.3438)\end{array}$ & $\begin{array}{c}0.0244^{* * *} \\
(5.4651)\end{array}$ & $\begin{array}{l}0.0244^{* * *} \\
(5.4802)\end{array}$ \\
\hline NWC & $\begin{array}{l}0.0265^{* * *} \\
(7.4475)\end{array}$ & $\begin{array}{c}0.0266^{* * *} \\
(7.4673)\end{array}$ & $\begin{array}{l}0.0266^{* * *} \\
(7.4709)\end{array}$ \\
\hline GROWTH & $\begin{array}{c}0.0036^{* * *} \\
(3.9214) \\
\end{array}$ & $\begin{array}{c}0.0036^{* * *} \\
(3.9027) \\
\end{array}$ & $\begin{array}{l}0.0036^{* * *} \\
(3.9166)\end{array}$ \\
\hline INVEST & $\begin{array}{c}-0.0283^{* * *} \\
(-2.9804) \\
\end{array}$ & $\begin{array}{c}-0.0287^{* * *} \\
(-3.0280)\end{array}$ & $\begin{array}{c}-0.0277^{* * *} \\
(-2.9246) \\
\end{array}$ \\
\hline ROA & $\begin{array}{c}0.0217^{* * *} \\
(2.7252)\end{array}$ & $\begin{array}{c}0.0139^{*} \\
(1.7161) \\
\end{array}$ & $\begin{array}{l}0.0219^{* * *} \\
(2.7628)\end{array}$ \\
\hline DIV & $\begin{array}{l}-0.0052^{* * *} \\
(-4.8867)\end{array}$ & $\begin{array}{l}-0.0057^{* * *} \\
(-5.2839)\end{array}$ & $\begin{array}{l}-0.0053^{* * *} \\
(-4.9385)\end{array}$ \\
\hline COMP & $\begin{array}{c}-0.0032 \\
(-0.7440) \\
\end{array}$ & $\begin{array}{c}-0.0033 \\
(-0.7569) \\
\end{array}$ & $\begin{array}{c}-0.0033 \\
(-0.7710) \\
\end{array}$ \\
\hline _cons & $\begin{array}{c}0.1749^{* * *} \\
(6.9232)\end{array}$ & $\begin{array}{c}0.1645^{* * *} \\
(6.4965) \\
\end{array}$ & $\begin{array}{l}0.1743^{* * *} \\
(6.9022)\end{array}$ \\
\hline IND & Yes & Yes & Yes \\
\hline YEAR & Yes & Yes & Yes \\
\hline $\mathrm{N}$ & 13691 & 13691 & 13691 \\
\hline $\mathrm{F}$ & $27.0312^{* * *}$ & $26.1150 * * *$ & $23.3004 * * *$ \\
\hline Adj. $R^{2}$ & 0.1153 & 0.1135 & 0.1167 \\
\hline
\end{tabular}

Note: $* * *$, and $* * *$ represent the significance levels of $10 \%$, $5 \%$, and $1 \%$, respectively.

\subsubsection{Internal control and cash flow risk}

This paper uses OLS regression to model (1) to test the relationship between internal control and cash flow risk. The regression results are shown in column (1) of Table 3. The regression coefficient of internal control (IC) is 0.0018 , and it is significant at the level of $1 \%$, indicating that high-quality internal control has a governance effect on cash flow risk to a certain extent and reduces cash flow risk. H1 has been verified.

\subsubsection{External audit and cash flow risk}

This paper uses OLS regression on model (2) to test the relationship between external audit and cash flow risk. The regression results are shown in column (2) of Table 3. The regression coefficient of external audit (AUDIT) is 0.0020 , and Significant at the 5\% level, indicating that high-quality external audit has a governance effect on cash flow risks to a certain extent, reducing cash flow risks. H2 has been verified.

\subsubsection{Substitution effect of internal control and external audit}

In order to test whether internal control and external audit have a substitution effect in the process of managing cash flow risk, this paper performs OLS regression on the plus model (3). The regression results are shown in column (3) of Table 3. The regression coefficient of the interaction term (IC*AUDIT) is 0.0018 , and it is significant at the $5 \%$ level, indicating that internal control and external audit have a substitution effect in the process of managing cash flow risks. $\mathrm{H} 3$ has been verified.

\section{Conclusion and Enlightenment}

\subsection{Conclusion}

This article selects the 2014-2019 Shanghai and Shenzhen A-share listed companies as the research sample, and discusses their governance effects on cash flow risks from the aspects of corporate internal control and external auditing, and what kind of interaction effects exist between the two in this process. The research found that: First, the improvement of internal control quality helps reduce corporate cash flow risks, that is, the two are significantly negatively correlated; second, the improvement of external audit quality can also help reduce corporate cash flow risks, that is, the two are significantly negatively correlated; third, internal control and external audit play a substitute effect in the governance process of corporate cash flow risk, that is, when the quality of external audit of an enterprise is low, improving the quality of its internal control can relatively effectively reduce the cash flow risk, and when the quality of internal control of the enterprise is low, improving the quality of external audit can relatively effectively reduce the cash flow risk.

\subsection{Enlightenment}

First, companies should pay full attention to and strengthen the construction of internal and external governance mechanisms, internal control and external auditing, and according to their actual operating conditions, through reasonable resource arrangements and management decisions, to obtain the maximum substitution effect of the two at a lower cost. Exertion of the degree to improve the level of corporate governance and risk management, reduce agency costs, and curb cash flow risks. For those enterprises whose internal control 
construction is not yet perfect or the effect of internal control implementation is not satisfactory, it is even more important to strengthen external audit supervision and hire high-quality accounting firms to conduct audits in order to obtain the effect of complementing each other. Similarly, for companies with poor audit quality, they should strengthen the construction and implementation of their own internal control system to replace the negative effects of the former, ensure the stable operation of the company, effectively prevent and suppress cash flow risks, and avoid falling into financial distress.

Second, government regulatory agencies should strictly implement the two-pronged policy of two supervision and restraint mechanisms, internal control and external auditing, in China's capital market. On the one hand, we should comprehensively strengthen the construction and implementation of the internal control system of Chinese enterprises, effectively promote the implementation of internal control related laws and regulations, and increase the compulsory strength of internal control information disclosure, establish a strict punishment mechanism, and promote the overall internal control quality of Chinese enterprises. The improvement of the company's risk resistance capabilities. On the other hand, it is necessary to strengthen the supervision and standardization of the auditing market in China, accelerate the improvement of the audit legal system, strengthen the practice management of accounting firms, and continuously promote China's accounting firms to become stronger, better, and more professional, so as to enhance high-quality auditing. The service supply is to give full play to the important role of independent audit in corporate governance, risk control and capital market supervision, and promote the healthy and orderly development of the audit market in China.

\section{References}

1. Chen Zhibin,Wang Shiyu.Study on the impact of product market competition on corporate cash flow risk_-Based on the dual considerations of industry competition and corporate competitive position[J].China Industrial Economy,2015(03):96108 .

2. Liu Hongxia.Research on the identification of corporate cash flow risk[J].Journal of Central University of Finance and Economics,2005(06):71$75+80$.

3. Xiao Tusheng,Sun Ruiqi,Yuan Chun.Study on the preventive value of corporate cash holdings under the impact of the new crown pneumonia epidemic [J].Economic Management,2020,42(04):175-191.

4. Liu Boyan, Han Liyan.Corporate governance, uncertainty and liquidity management[J].World Economy,2010,33(02):141-160.

5. Li Wei'an,Dai Wentao.The relationship framework of corporate governance, internal control, and risk management_Based on the perspective of strategic management[J].Auditing and Economic Research,2013,28(04):3-12.

6. Li Hongwei,Wang Shiyu.Internal control, marketization process and corporate cash flow risk[J].Chinese Certified Public Accountant,2017(05):52-56+3.

7. Cao Guohua,Luo Lianhu.Internal Control, Accounting Firm Selection and Real Earnings Management__Based on the Empirical Evidence of Shenzhen A-Share Listed Companies[J].Journal of Nanjing Audit University,2015,12(03):45-52.

8. Xie Shengwen, Jiang Xuhan, Yan Huanmin. Highquality audit, management power and agency cost[J].Contemporary Finance,2015(03):109-118.

9. Zhao Yi, Ni Guoqiang.Auditor's industry expertise, property rights and investment efficiency[J].Audit Research,2020(01):87-95.

10. Gong Yifei, Luo Kaixin, Long Sitong. Abnormal audit fees, audit quality and stock price collapse risk[J].Journal of Beijing Technology and Business University (Social Science Edition),2021,36(01):56$67+80$.

11. Zhang Huili,Wu Youhong.Internal Control, Cash Holding and Economic Consequences[J].Accounting Research,2014(03):71-78+96.

12. Liu Qiliang, Luo Le, Zhang Yaman, Chen Hanwen. Executive Centralization, Internal Control and Accounting Information Quality[J].Nankai Management Review,2013,16(01):15-23.

13. Li Wanfu,Lin Bin,Song Lu.The role of internal control in corporate investment: efficiency promotion or inhibition?[J].Management World,2011(02):81$99+188$.

14. Jensen M C, Meckling W H. Theory of the firm: Managerial behaviour, agency costs and ownership structure[J]. 1976, 3(4):0-360.

15. Gu Naikang,Sun Jinjun.Financing constraints, cash flow risks and preventive motivations for cash holdings[J].Business Economics and Management,2009(04):73-81.

16. Zhang Jiaxing, Fu Shaozheng.Internal Control, CPA Audit and Earnings Management[J].Auditing and Economic Research,2014,29(02):3-13. 